\title{
OUTRORA AGORA: TESSITURAS CONTEMPORÂNEAS
}

\author{
Andréa Figueiredo Leão Grants \\ Gizelle Kaminski Corso \\ Jair Zandoná \\ Stélio Furlan \\ Susan A. de Oliveira \\ Tanay Gonçalves Notargiacomo \\ Universidade Federal de Santa Catarina
}

Vera Sabino, na tela Rendeira da Lagoa da Conceição, surpreende os devaneios de uma jovem mulher com paisagem ao fundo sem que os hábeis dedos descuidem do maneio dos bilros. Entre imaginação e labor a renda se faz. Inevitável não evocar a ideia já consagrada de que todo tex to é um tecido, tessitura. Por sinonímia, especialmente dedicado ao estudo das condições de possibilidade das literaturas contemporâneas de expressão portuguesa, equivale dizer que o presente número foi urdido numa parceria entre a revista Anuário de Literatura, publicação do Programa de Pós-Graduação em Literatura (UFSC) e o Real Gabinete Português de Leitura, sediado no Rio de Janeiro, cuja concepção surgiu em decorrência das recentes comemorações do Ano de Portugal no Brasil e Ano do Brasil em Portugal.

Concorde a esse horizonte de expectativas, o volume 18 número 2 se abre com Damas e Donas de si: leituras de Minha Senhora de Mim de Maria Teresa Horta e Minha Senhora de Quê de Ana Luísa Amaral, de Fabio Mario da Silva, que procura identificar no corpus de análise evidenciado no título do seu artigo uma poética na qual o "eu" lírico constrói uma obra sui generis dentro de uma perspectiva feminista (feminina). Lido como "o intelectual em trânsito", o poeta moçambicano falecido recentemente Virgílio de Lemos é palavra-chave do artigo de Luciana Brandão Leal. A autora investiga em que medida a poesia de Virgílio Lemos produzida entre 1944-1963 se revelou rebelde e transgressora em relação ao gosto literário predominante em Moçambique e, ao considerar a produção 
heteronímica (Duarte Galvão, Bruno Reis e Li Lee Yang) avalia o modo pelo qual suplementa as contribuições inovadoras das vanguardas europeias e do modernismo português.

Entrelaça-se igualmente ao presente número as Notas sobre a poesia portuguesa da década de 70: o caso de Al Berto, de Leonardo de Barros Sasaki, que ousa uma visão de conjunto da lírica portuguesa contemporânea, dedicando especial atenção àquela produzida na década de 70. Com destaque para a poesia de Al Berto, o autor centra o investimento discursivo na relação no caráter declaratório e dialogante da poesia; a não-coincidência entre poema e poesia e a questão da vinculação/constituição do sujeito poético. Já em $\mathbf{O}$ tempo no conto “Testemunha”, de Lídia Jorge, Letícia Braz da Silva objetiva analisar a estrutura temporal do referido conto entrançando como referencial teórico os estudos do texto narrativo proposto por Gérard Genette, Paul Ricoeur e Benedito Nunes. O artigo objetiva pensar em que medida a alteração da ordem temporal (anacronia) e a organização discursiva subvertida por meio de recuos temporais (analepses) contribuem para a motivação da história.

De Evita a Eva Lopo, do romance de Lídia Jorge ao cinema de Margarida Cardoso: a transposição de uma personagem intransponível, de Camila Canali Doval põe em cena um estudo sobre a adaptação cinematográfica do romance $A$ costa dos murmúrios (1988). Afora um trevelling sobre o que se convencionou chamar "cinema português", na observação da forma com que a diretora Margarida Cardoso interpretou e transpôs, em 2004, o romance de Lidia Jorge, ajustando o foco de análise à atuação das mulheres diante do conflito enfocado no livro encontra-se o interesse do artigo. No artigo A santa e a sereia no espaço/tempo das águas moçambicanas, Neiva Kampff Garcia se concentra na análise do romance $O$ outro pé da sereia, de Mia Couto, publicado em 2006, identificando a formalização de um encontro dos imaginários europeu e africano no qual se mesclam o pensamento e a voz da cultura portuguesa colonialista do século XVI e questões identitárias da sociedade moçambicana do século XXI.

Embora eleja como referencial teórico questões associadas à metaficção historiográfica contemporânea (a noção de herói problemático, a revisão das ideologias e dos mitos, a questão dos limiares entre história e ficção) no artigo Entre o pampa e o mar: questões de civilização e barbárie, Lívia Petry Jahn privilegia uma reflexão sobre as noções de civilização e barbárie estendidas aos romances $O$ Pintor de Retratos, de Assis Brasil (2001) e As Naus, de Lobo Antunes (2011). Enquanto que no artigo Outro mar, outro eu: uma leitura sobre a natureza metafórica de Paisagem com mulher e mar ao fundo, Mariana Marques de Oliveira objetiva avaliar a poesia de Teolinda Gersão, publicada oito 
anos após da Revolução dos Cravos, tendo como ar do tempo as décadas de regime ditatorial português, compreendendo a paisagem, o olhar sobre mar, enquanto símbolo da cultura, memória e história portuguesas.

E, para arrematar a tessitura do presente número, somam-se seis artigos de temática livre. Aquém-mar, em Demandas do presente: Traduzir-se, de Ferreira Gullar, Sandro Adriano da Silva sugere uma leitura do poema como exercício lírico-existencial cuja elaboração estética articula metáforas sintomáticas de uma subjetividade cindida. O autor considera rentável uma aproximação entre alguns pressupostos da psicanálise à teoria e crítica de poesia, para se alcançar um horizonte de compreensão sobre a poesia de Ferreira Gullar.

Avaliar contrastivamente o(s) Amor(es) de Clarice e Rui Torres é a promessa do artigo de Keilla Conceição Petrin Grande. A autora aborda o conto Amor de Clarice Lispector e o poema Amor de Clarice, de Rui Torres, lendo-os a partir do conceito de "hipotexto" segundo definição de Genette, e da tradução intersemiótica conforme os trabalhos de Julio Plaza e Claus Clüver, para os quais a "tradução" não se pensa como mera transferência de sentido do original que deve a ele se subordinar, mas, sim, enquanto uma atividade igualmente criadora. Já o título do artigo A importância da natureza para a construção de uma identidade feminina na poesia Que transpõe $O$ halo, de Marcele Aires: uma análise sob o ponto de vista do ecofeminismo, Marciano Lopes Silva é autoexplicativo.

Letter: a carta/letra e o jogo da correspondência, de Joacy Ghizzi Neto, revisita uma leitura do conto "A carta roubada" de Edgar Alan Poe amarrando-a às análises propostas a respeito por Lacan, Derrida e Nancy. Afora apostar nos desdobramentos lógicos da similitude do significante letter/lettre, leia-se carta/letra, conclui-se com uma reflexão sobre o procedimento da correspondência entre artistas/poetas enquanto um jogo de posições ambivalentes, em vez de mera troca estática de mensagens entre remetente e destinatário.

Em Escrita, performance e representação de si, Nayara Marfim Gilaberte Bezerra aposta no conceito de autoria como performance amarrando-o à reflexão sobre os espaços de e(u)nunciação utilizados por João Paulo Cuenca, escritor que se faz valer das plataformas digitais como meios para divulgação, apresentação e criação de suas obras. Finalmente, no artigo Teoria Crítica e Literatura: a distopia como ferramenta de análise radical da modernidade, Leomir Cardoso Hilário recorta três obras para análise, a saber, 1984, de Orwell, Fahrenheit 451, de Bradbury e Admirável Mundo Novo, de Huxley. Se o autor esclarece, de imediato, que relações entre literatura e sociedade, mediadas pela teoria crítica da primeira geração da Escola de Frankfurt definem as motivações do seu artigo, não é menos 
certo dizer que também investiga o modo pelo qual as "distopias" se constituem como meios de análise da sociedade contemporânea.

Resta agradecer a artista plástica Vera Sabino pela sugestão da capa, um quadro (acrílica sobre eucatex, 0,50X0,60) cujo tema, uma jovem rendeira com a igreja de Santo Antônio de Lisboa ao fundo ambientado na Ilha de Santa Catarina, pareceu-nos uma moldura perfeita para este número da Anuário de Literatura, como dissemos, especialmente dedicado aos estudos sobre as literaturas de expressão portuguesa na contemporaneidade. Cumpre registrar nossa gratidão à Profa. Gilda Santos e aos investigadores do Polo de Pesquisa sobre Relações Luso-Brasileiras (PPRLB), sediado no Real Gabinete Português de Leitura, - que desenvolvem estudos sobre diferentes aspectos das relações luso-brasileiras, com uma perspectiva crítica interdisciplinar — , pelo indispensável auxílio na divulgação da proposta e na avaliação dos textos submetidos para publicação. E pensamos que assim, antes tarde, fizemos valer as motivadoras palavras de Fernando Pessoa sobre essas relações: "urge que estreitemos inteligências"!

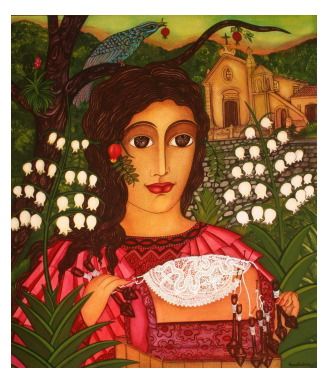

